\title{
Seroprevalence of Leptospira infection in bats roosting in human settlements in Morogoro municipality in Tanzania
}

\author{
GEORGIES F. MGODE ${ }^{*}$, HURUMA A. MBUGI², GINETHON G. MHAMPHI', DICKSON NDANGA ${ }^{2}$ and EVANCE L. \\ NKWAMA ${ }^{2}$ \\ ${ }^{1}$ Pest Management Centre, Sokoine University of Agriculture, P.O. Box 3110, Morogoro, Tanzania \\ ${ }^{2}$ Department of Wildlife Management, Sokoine University of Agriculture, Morogoro, Tanzania
}

\begin{abstract}
Leptospirosis is a neglected emerging infectious disease with high burden in Africa. Major reservoirs of leptospirosis are rodents and other small mammals. Studies of leptospirosis in bats and the extent to which they contribute to its transmission to humans and domestic animals in Tanzania are lacking. The objective of this study was to determine the prevalence of leptospirosis and local Leptospira serovars in bat colonies found around human settlements in Morogoro, Tanzania. In this study, mist nets were used to capture bats at Sokoine University of Agriculture main campus, whereas bats roosting on trees at Nunge A, Nunge B and Mwere primary school were captured manually. Leptospirosis was determined using the gold standard microscopic agglutination test for determination of Leptospira antibodies. Six live Leptospira serovars including local Leptospira serovar Sokoine, Kenya and Lora reported in rodents and domestic animals in Tanzania, and reference serovars Hebdomadis, Canicola and Pomona were used in the study. Leptospirosis prevalence was high in bats (19.4\%) and higher within colonies (27.3\%). Leptospira serovar Sokoine was more prevalent (19.4\%) compared to serovars Kenya (2.8\%) and Lora (2.8\%). Serovars Pomona, Canicola and Hebdomadis were not detected in bats. In conclusion, bats are potential reservoir and transmitter of Leptospira serovar Sokoine, hence should be prevented to access houses and roosting in human settlements to avoid public health risks. Routine diagnosis of human leptospirosis is needed in Tanzania as evidence show a high prevalence of Leptospira in reservoir hosts interacting with humans.
\end{abstract}

Keywords: Leptospirosis, bats, reservoir, Tanzania

\section{Introduction}

Leptospirosis is among the highly neglected zoonotic diseases in tropical and subtropical countries despite its high prevalence especially in Africa (Pappas et al., 2008). The disease is caused by spirochete bacterium of the genus Leptospira. Leptospira serovars may infect certain host animals and cause different disease manifestations (Bharti et al., 2003). Serovar - host specificity is common in leptospirosis epidemiology. Therefore, serovar is the lowest taxonomic unit which have implication in serological diagnosis of leptospirosis. Most leptospirosis cases are undiagnosed or misdiagnosed due to lack of awareness of the disease and difficulties in carrying out laboratory confirmation tests (WHO, 2011). Use of serovars unrelated to the infecting serovar in serodiagnosis of leptospirosis may lead to misdiagnosis of this disease. It is estimated that up to $20 \%$ of undefined febrile illness are due to leptospirosis (WHO, 2011). The distribution pattern of human leptospirosis worldwide shows that the highest median annual incidence occurs in Africa (95.5 per 100,000 population) followed by the Western Pacific (66.4), the Americas (12.5), South-East Asia (4.8) and Europe (0.5) (WHO, 2011). High burden of leptospirosis is driven by fewer economic resources thus people living in rural and semi-urban slums are more vulnerable.

Recent studies from the African region shows high prevalence of leptospirosis in villagers engaged with gold-panning in Gabon (Bertherat et al., 1999), in small mammals in Benin (Houemenou et al., 2013) and in rodents in urban settlements in Kenya (Halliday et al., 2013). A study from Uganda also shows high prevalence of leptospirosis in buffalos (42.39\%) and cattle (29.35\%) (Atherstone et al., 2013). In Tanzania, several Leptospira serovars including Sokoine, Kenya, Lora, Pomona, Canicola and Hebdomadis have been identified to infect rodents and domestic animals especially in Morogoro (Machang'u et al., 1997; Machang'u et al., 2004; Mgode

\footnotetext{
*Correspondence: Georgies F. Mgode; Email: gfmgode@hotmail.com, gmgode@suanet.ac.tz
} 
et al., 2006; Ahmed et al., 2006). A recent report by Biggs et al. (2011) also shows a high prevalence of leptospirosis in human patients with fevers in northern Tanzania.

Major reservoirs of leptospirosis are rodents and other small mammals (Babudieri, 1958; Everard, 1992). The disease is also reported in bats in South America and Australia (Matthias et al., 2005; Bessa et al., 2010; Tulsiani et al., 2011). Studies of leptospirosis in bats and the extent to which they contribute to its transmission to humans and domestic animals in Tanzania and Africa in general are lacking. Bats which share habitats with humans increase the potential risk of transmitting leptospirosis to humans (Daszak et al., 2000; Calisher et al., 2006; Mühldorfer, 2013). The objectives of this study were to determine the prevalence of leptospirosis and local Leptospira serovars in bat colonies roosting around human settlements and school premises; and to establish new potential reservoir of Leptospira pathogens in Morogoro municipality in Tanzania.

\section{Materials and Methods}

\section{Study sites and sampling of bats}

Mist nets were used to capture bats at Sokoine University of Agriculture (SUA) main campus. In addition, bats roosting on trees (Figure 1) at Nunge A, Nunge B and Mwere primary school were captured manually and transported in ventilated plastic buckets to Sokoine University of Agriculture, Pest Management Centre. Blood samples were collected from orbital vein and by heart puncture after anaesthetizing the animals with di-ethyl ether. Serum for serological detection of Leptospira antibodies was separated from blood by centrifugation and thereafter stored at $-20^{\circ} \mathrm{C}$ until used.

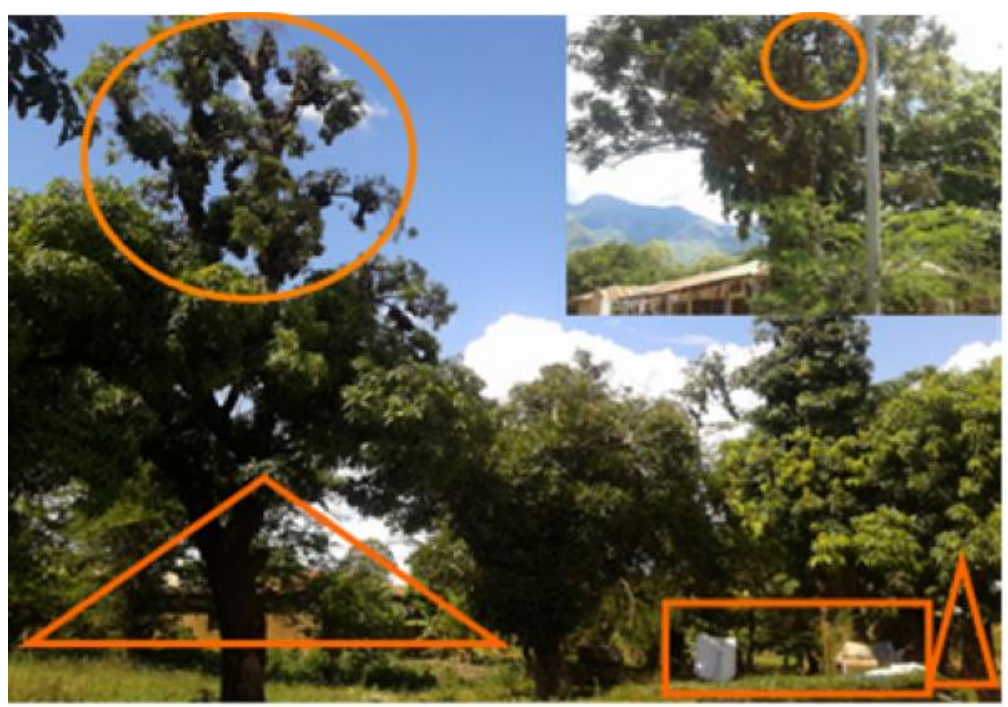

Figure 1: Bats roosting on mango tree near residential houses (triangles) in Morogoro

\section{Microscopic agglutination test for Leptospira antibodies}

The gold standard microscopic agglutination test (MAT) used for serodiagnosis of leptospirosis was applied to determine Leptospira antibodies in bats' serum as described elsewhere (Cole et al., 1973; Goris \& Hartskeerl, 2013). Six live Leptospira serovars including local Leptospira serovar Sokoine, serovar Kenya and serovar Lora reported in rodents and domestic animals in Tanzania including Morogoro areas, and reference serovars Hebdomadis, Canicola and Pomona were used in the study.

Briefly, selected Leptospira serovars were inoculated into fresh EMJH (Ellinghausen and McCullough, modified by Johnson and Harris) culture medium and incubated at $30^{\circ} \mathrm{C}$ for $5-8$ days. Well grown Leptospira culture with density of $300 \times 10^{8}$ leptospires $/ \mathrm{ml}$ was used as antigen mixed 
with equal volume of serum diluted serially in phosphate buffered saline ( $\mathrm{pH} 7.0)$. The antigenserum mixture was incubated at $30^{\circ} \mathrm{C}$ for 2 hours and examined for agglutination under dark field microscopy (Cole et al., 1973; Goris \& Hartskeerl, 2013).

\section{Ethical considerations}

Live bats were safely handled in compliance with the "Animal Research: Reporting In Vivo Experiments" guidelines and the Helsinki Declaration.

\section{Results}

A total of 36 bats were captured and tested for Leptospira antibodies. Leptospira antibodies were detected in 7 out of $36(19.4 \%)$ bats captured. Bats infected with leptospires were from diverse colonies roosting at Mwere primary school, Nunge A and Nunge B sites (Table 1) all located within human settlements in the town centre (Figure 1). The prevalence of leptospirosis within the three bats colonies was high $(15.4 \%, 25 \%$ and $27.3 \%$ respectively) (Table 1). Leptospira antibodies were not detected in four solitary bats collected from Sokoine University of Agriculture, main campus.

Table 1: Leptospirosis prevalence in bats collected in May 2013, Morogoro municipality, Tanzania

\begin{tabular}{llllll}
\hline Collection site & Mode of life & $\begin{array}{l}\text { Number } \\
\text { animals }\end{array}$ & $\begin{array}{l}\text { of } \\
\text { positive }\end{array}$ & $\begin{array}{l}\text { Prevalence (\%) } \\
\text { within colonies }\end{array}$ \\
\hline SUA main campus & Solitary bats & 4 & 0 & 0 \\
Nunge A & Colonial bats & 8 & 2 & 25.0 \\
Nunge B & Colonial bats & 11 & 3 & 27.3 \\
Mwere primary school & Colonial bats & 13 & 2 & 15.4 \\
\hline
\end{tabular}

The antibodies detected in bats were of Leptospira serovar Sokoine $(n=7)(19.4 \%)$; serovar Kenya $(n=1)(2.8 \%)$; and serovar Lora $(n=1)(2.8 \%)$. The specimens which reacted with serovars Kenya and Lora also reacted with serovar Sokoine suggesting cross-reaction or potential infection with more than one serovar (Table 2). Serovar Sokoine was detected in bats from all three colonies roosting on mango trees in town centre including trees planted on edges of Mwere primary school play grounds.

Table 2: Potential cross-reaction and/or infection of bats with more than one Leptospira serovar revealed by MAT using six Leptospira serovars

\begin{tabular}{|c|c|c|c|c|c|c|c|c|}
\hline$S / n$ & $\begin{array}{l}\text { Sample } \\
\text { ID* }\end{array}$ & Locality & Sokoine & Kenya & Lora & Pomona & Canicola & Hebdomadis \\
\hline 1 & $\mathrm{~N} 2$ & Nunge A & + & - & - & - & - & - \\
\hline 2 & N6 & Nunge A & + & - & + & - & - & - \\
\hline 3 & NB2 & Nunge B & + & + & - & - & - & - \\
\hline 4 & NB7 & Nunge B & + & - & - & - & - & - \\
\hline 5 & NB10 & Nunge B & + & - & - & - & - & - \\
\hline 6 & MME5 & $\begin{array}{l}\text { Mwere } \\
\text { p/school }\end{array}$ & + & - & - & - & - & - \\
\hline 7 & MME13 & $\begin{array}{l}\text { Mwere } \\
\text { School }\end{array}$ & + & - & - & - & - & - \\
\hline \multicolumn{3}{|c|}{ ar preva } & 19.4 & 2.8 & 2.8 & 0 & 0 & 0 \\
\hline
\end{tabular}

* Other 29 bats were negative for six Leptospira serovars tested above

\section{Discussion}


This study shows a high prevalence of leptospirosis in bats in Morogoro Municipality, suggesting potential public health risks to people sharing habitats, living closer to bat colonies or doing socio-economic activities in environment contaminated with bat's urine and faeces. Those at higher risk include children playing on grounds under trees infested with bats. This is the first report of Leptospira infection in bats from Tanzania. Leptospira serovar Sokoine is the most prevalent in these bats. Leptospirosis prevalence within bat colonies was between $15.4 \%$ and $27.3 \%$ but absent in solitary bats. These results suggest a high transmission rate of Leptospira pathogens within bat's colonies than in solitary bats which live in smaller numbers contrary to aggregating bats which form large colonies roosting on trees and building structures.

Lack of aggregation behaviour in solitary bats likely minimizes chances of transmission of Leptospira in these bats, whereby social bats have more chances of transmitting the pathogens within colonies. Serovars Lora and Kenya had a low prevalence. These three serovars were previously reported in rodents and cattle from Morogoro (Machang'u et al., 2004; Mgode et al., 2006; Ahmed et al., 2006), suggesting that they are common serovars in this area. The high prevalence of local serovar Sokoine in bats suggest involvement of bats in transmission of leptospirosis to other animals in Morogoro confirming recent reports that bats are reservoirs of Leptospira and transmit these pathogens to other animals in Australia (Tulsiani et al., 2011).

Presence of Leptospira serovar Sokoine in bats show that serovar Sokoine has no host specificity as it has already been widely reported in cattle, rodents (Mgode et al., 2006; Ahmed et al., 2006), fish (G.F. Mgode, unpubl) and now in bats. This serovar belongs to Leptospira kirschneri species serogroup Icterohaemorrhagiae consisting of serovars mostly occurring in eastern, central Africa and the Indian ocean islands located near east Africa (Faine et al., 1999; Bourhy et al., 2010). The low prevalence of Serovars Kenya and Lora in bats suggests host specificity. The serovar Kenya has been commonly isolated from African giant pouched rats (Cricetomys spp.) (Kranendork et al., 1968; Machang'u et al., 2003; Machang'u et al., 2004). Host specificity is a possible reason for absence of serovars Canicola, Hebdomadis and Pomona in bats. These serovars are reported in dogs, rodents, pigs and cattle from Morogoro (Ahmed et al., 2006; Kessy et al., 2010).

These findings indicate the need for inclusion of serovar Sokoine and other serovars belonging to L. kirschneri and L. borgpetersenii species in the diagnosis or surveillance of leptospirosis in humans and animals in African region which is reported to have the highest burden of leptospirosis globally (WHO, 2011) but the disease is not given adequate priority although it is estimated that $20 \%$ of febrile illness of unknown origin is due to leptospirosis (WHO, 2011).

Some of the risk factors which may promote human contact with potential pathogens carried by bats such as Leptospira include living in houses closer to bat colonies; hanging washed clothes to dry under or closer to trees with bats colony; presence of kiosk shops in houses closer to bat colonies, as observed at Nunge street in Morogoro; contact with water from Morogoro river that pass closer to trees with bat colony at Mwere primary school where children often do sport fishing. Use of water from this river for washing cars and growing vegetables along the river could be another risk factor. Potential risk factors for animal leptospirosis in this area may include presence of free range goats and stray dogs which often visits domestic garbage collection points near bat colonies. Determination of the magnitude of leptospirosis infections in risk populations such as people living in houses closer to bat colonies is much needed. This could be achieved by using robust techniques such as specific PCR for detection of Leptospira DNA to reveal the actual prevalence than serological tests alone which cannot detect leptospirosis caused by serovars not included in the microagglutination test (Mgode et al., 2005). Isolation of leptospires from bats and classification using multidisciplinary approaches (Mgode et al., 2010) is also required to obtain insights on other potential local circulating serovars and their pathogenicity status.

Control measures that prevent bats from entering and inhabiting buildings (houses and 
schools) are necessary. For example, all openings and cracks in houses should be covered using wire mesh or other materials to prevent bats access. Other ecologically, non-destructive and environmentally friendly methods that ensure species conservation such as relocating bats roosting in trees in town centre, houses and school buildings through coordinated and simultaneous disturbance of the bat colonies could be useful. This could prevent transmission of various zoonotic bacterial, fungal and viral pathogens (http://www.cdc.gov/features/bats) to humans especially children playing on grounds under trees infested with bats, school pupils in class rooms contaminated with bat's urine and faeces. Currently, residents in some parts of Morogoro occasionally burn old-used tyres put under infested trees to chase away bats. However, bats usually return to their colonies once smoke has disappeared. This method is therefore not sustainable and causes air pollution.

In conclusion, bats are potential reservoir and transmitter of Leptospira serovar Sokoine, in Morogoro Municipality in Tanzania. It is important that bats are prevented to access houses and roosting in human settlements to avoid public health risks. Routine diagnosis of human leptospirosis is needed in Tanzania as evidence show a high prevalence of Leptospira in reservoir hosts interacting with humans.

\section{Acknowledgements}

This study received financial support from the Tanzania Higher Education Students' Loans Board. We acknowledge the logistical assistance by the Sokoine University of Agriculture Pest Management Centre.

\section{References}

Ahmed, N., Devi, S.M., Valverde Mde, L., Vijayachari, P., Machang'u, R.S., Ellis, W.A. \& Hartskeerl, R.A. (2006) Multilocus sequence typing method for identification and genotypic classification of pathogenic Leptospira species. Annals of Clinical Microbiology and Antimicrobials 5, 28.

Atherstone, C., Picozzi, K. \& Kalema-Zikusoka, G. (2013) Seroprevalence of Leptospira Hardjo in Cattle and African Buffalos in Southwestern Uganda. American Journal of Tropical Medicine and Hygiene 90:288-290.

Babudieri, B. (1958) Animal reservoirs of leptospires. Annals of New York Academy of Sciences 70, 393-413.

Bertherat, E., Renaut, A., Nabias, R., Dubreuil, G. \& Georges-Courbot, M.C. (1999) Leptospirosis and Ebola virus infection in five gold-panning villages in northeastern Gabon. American Journal of Tropical Medicine and Hygiene 60, 610-615.

Bharti, A.R., Nally, J.E., Ricaldi, J.N., Matthias, M.A., Diaz, M.M., Lovett, M.A., Levett, P.N., Gilman, R.H., Willig, M.R., Gotuzzo, E. \& Vinetz, J.M. (2003) Leptospirosis: a zoonotic disease of global importance. Lancet Infectious Diseases 3, 757-771.

Biggs, H.M., Bui, D.M., Galloway, R.L., Stoddard, R.A., Shadomy, S.V., Morrissey, A.B., Bartlett, J.A., Onyango, J.J., Maro, V.P., Kinabo, G.D., Saganda, W. \& Crump, J.A. (2011) Leptospirosis among hospitalized febrile patients in northern Tanzania. American Journal of Tropical Medicine and Hygiene 85, 275.

Bourhy, P., Collet, L., Clement, S., Huerre, M., Ave, P., Giry, C., Pettinelli, F. \& Picardeau, M. (2010) Isolation and characterization of new Leptospira genotypes from patients in Mayotte (Indian Ocean). PloS Neglected Tropical Diseases 4, e724.

Calisher, C.H., Childs, J.E., Field, H.E., Holmes, K.V. \& Schountz, T. (2006) Bats: important reservoir hosts of emerging viruses. Clinical Microbiology Review 19, 531-545.

Centers for Disease Control and Prevention. Features: Take caution when bats are near. http://www.cdc.gov/features/bats [Cited 2013 October 16]. 
Cole, J.R., Sulzer, C.R. \& Pursell, A.R. (1973) Improved microtechnique for the leptospiral agglutination test. Applied Microbiology 25, 976-980.

Daszak, P., Cunningham, A.A. \& Hyatt, A.D. (2000) Emerging infectious diseases of wildlife-threats to biodiversity and human health. Science $287,443-449$.

Everard, C.O.R. (1992) The epidemiology of leptospirosis. In Leptospirosis on the African continent. Proc CEC/STD 3 Research Meeting, Harare, Zimbabwe, p 31.

Faine, S., Adler, B., Bolin, C. \& Perolat, P. (1999) Leptospira and Leptospirosis. Melbourne: MediSci.

Goris, M.G. \& Hartskeerl, R.A. (2013). Leptospirosis serodiagnosis by the microscopic agglutination test. Current Protocols in Microbiology $12 \mathrm{E}-5$.

Halliday, J.E., Knobel, D.L., Allan, K.J., de C Bronsvoort, B.M., Handel, I., Agwanda, B., Cutler, S.J., Olack, B., Ahmed, A., Hartskeerl, R.A., Njenga, M.K., Cleaveland, S. \& Breiman, R.F. (2013) Urban leptospirosis in Africa: a cross-sectional survey of Leptospira infection in rodents in the Kibera urban settlement, Nairobi, Kenya. American Journal of Tropical Medicine and Hygiene 89, 1095.

Houemenou, G., Ahmed, A., Libois, R. \& Hartskeerl, R.A. (2013) Leptospira spp. prevalence in small mammal populations in Cotonou, Benin. ISRN Epidemiology 2003.

Kessy, M.J, Machang'u, R.S. \& Swai, E.S. (2010) A microbiological and serological study of leptospirosis among pigs in the Morogoro municipality, Tanzania. Tropical Animal Health and Production 42, 523-530.

Kranendork, O., Wolff, J.W., Bohlander, J.W., Roberts, J.M.D., De Geus, A. \& Njenga, R. (1968) Isolation of new Leptospira serovars in Kenya. World Health Organization (WHO) Zoonotics $111,1-5$.

Machang'u, R.S., Mgode, G. \& Mpanduji, D. (1997) Leptospirosis in animals and humans in selected areas of Tanzania. Belgian Journal of Zoology 127, 97-104.

Machang'u, R., Mgode, G., Asenga, J., Mhamphi, G., Hartskeerl, R., Goris, M., Cox, C., Weetjens, B. \& Verhagen, R. (2003) Characterization of Leptospira isolates from captive giant pouched rats, Cricetomys gambianus. In: Rats, Mice and People, Rodent Biology and Management. Singleton, G.R., Hinds, L.A., Krebs, C.J., Spratt, M.D. (eds). Australian Centre for International Agriculture Research, Canberra, pp 40-42.

Machang'u, R.S., Mgode, G.F., Assenga, J., Mhamphi, G., Weetjens, B., Cox, C., Verhagen, R., Sondij, S., Goris, M.G. \& Hartskeerl, R.A. (2004) Serological and molecular characterization of Leptospira serovar Kenya from captive African giant pouched rats (Cricetomys gambianus) from Morogoro Tanzania. FEMS Immunology and Medical Microbiology 41, 117121.

Matthias, M.A., Díaz, M.M., Campos, K.J., Calderon, M., Willig, M.R., Pacheco, V., Gotuzzo, E., Gilman, R.H. \& Vinetz, J.M. (2005) Diversity of bat-associated Leptospira in the Peruvian Amazon inferred by Bayesian phylogenetic analysis of $16 \mathrm{~S}$ ribosomal DNA sequences. American Journal of Tropical Medicine and Hygiene 73, 964-974.

Mgode, G.F., Mhamphi, G., Katakweba, A., Paemelaere, E., Willekens, N., Leirs, H., Machang'u, R.S. \& Hartskeerl, R.A. (2005) PCR detection of Leptospira DNA in rodents and insectivores from Tanzania. Belgian Journal of Zoology 135, 17-19.

Mgode, G.F., Machang'u, R.S., Goris, M.G., Engelbert, M., Sondij, S. \& Hartskeerl, R.A. (2006) New Leptospira serovar Sokoine of serogroup Icterohaemorrhagiae from cattle in Tanzania. International Journal of Systematic and Evolutionary Microbiology 56, 593-597.

Mgode, G.F., Machang'u, R.S., Collares-Pereira, M., Vieira, M.L., Goris, M.G.A., Engelbert, M. \& Hartskeerl, R.A. (2010) Challenges in determining the pathogenicity status of Leptospira isolates with phenotypic methods: The need for a polyvalent approach. African Journal of Microbiology Research 4, 2528-2533.

Mühldorfer, K. (2013) Bats and bacterial pathogens: a review. Zoonoses and Public Health 60, 93103. 
Pappas, G., Papadimitriou, P., Siozopoulou, V., Christou, L. \& Akritidis, N. (2008) The globalization of leptospirosis: worldwide incidence trends. International Journal of Infectious Diseases 12, 351-357.

Tulsiani, S.M., Cobbold, R.N., Graham, G.C., Dohnt, M.F., Burns, M.A., Leung, L.K., Field, H.E., Smythe, L.D. \& Craig, S.B. (2011) The role of fruit bats in the transmission of pathogenic leptospires in Australia. Annals of Tropical Medicine and Parasitology 105, 71-84.

World Health Organization. (2011) Report of the second meeting of leptospirosis burden epidemiology reference group. Geneva, Switzerland: World Health Organization. 